\title{
A rational cure for prereproductive stress syndrome M Häyry
}

\author{
Since human reproduction is arguably both irrational and immoral, those who seek help before \\ conceiving could be advised it is all right not to have children.
}

M any women and men, usually in the 20-50 age cohort, suffer from a condition that can be called prereproductive stress syndrome. The primary symptom is that these individuals have an urge to have children. Secondary symptoms, which are many and varied, can include a conviction that this urge is self evidently reasonable, and an illusion that others should help them in satisfying it. The syndrome typically disappears, at least for the time being, when the urge is met, and the standard treatment is, accordingly, pronatal counselling. In cases where the sufferers cannot have children of their own on their own, further approved treatments include artificial insemination, in vitro fertilisation, surrogate pregnancies, prenatal selection, and, in some jurisdictions, attempts to clone individuals. While pronatal counselling is widely seen as unproblematic, all the other alternatives are associated with difficult questions of ethics and health policy.

In professional discussions concerning assisted reproduction and genetic selection, ${ }^{1-6}$ scientists and ethicists alike have, however, overlooked one fundamental question, namely, is it rational to have children in the first place. If it is not, then the use of advanced technologies in this context should be reassessed, and recommendations to possible parents reformulated. The least controversial intervention would be to let possible parents know that their urge is not necessarily rational. This view can be based on the following considerations.

\section{POSSIBLE BELIEFS}

I am convinced it is irrational to have children. This conviction is based on two beliefs that I hold. I believe it would be irrational to choose the course of action that can realistically lead to the worst possible outcome. And I believe that having a child can always realistically lead to the worst possible outcome, when the alternative is not to have a child.

I am also personally convinced that it is immoral to have children. Children can suffer, and I think it is wrong to bring about avoidable suffering. By deliberately having children parents enable suffering which could have been avoided by reproductive abstinence. This is why I believe that human procreation is fundamentally immoral.

I am fully aware that other people have different moral views on this and other matters. I do not think moral considerations are universal, overriding commands, as some philosophers do. I think they are opinions which I am entitled to express freely in private and in public, as I think other people should be entitled to express their moral opinions. The prudence and legal acceptability of doing so are sometimes separate issues.

In what follows, I will first give the reasons I have for holding my two beliefs concerning rationality. I will then go on to consider the immorality of having children. In conclusion, I will sketch the implications of my arguments, if sound, for the advice given to possible parents.

\section{THE RATIONALITY OF RISK AVERSION}

The idea of avoiding risks that I have in mind is known in decision theory as the maximin strategy. When we consider what we should do in a given situation, we have typically two or more options. It is also usual that we do not know with any certainty what the outcomes of our action or inaction will be. One action option can produce either good or bad outcomes. Another can be expected to bring about greater or lesser amounts of good. Another can lead to bad outcomes, but we cannot be sure to what extent. Yet others can produce neither good nor bad results. The maximin strategy tells us to choose, under such circumstances, the option that maximises the minimum outcome, and to avoid the options where the worst outcomes can materialise. ${ }^{78}$

The maximin strategy was introduced to moral and political theory by John Rawls, who used it as a cornerstone of his theory of justice. He argued that it is rational, under uncertainty about one's own place in a future society, to choose political institutions which can be expected to benefit those who turn out to be in the worst position in that society. ${ }^{9}$ Reasonable precaution dictates that we should not pick out policies, or courses of action, which can realistically have disastrous consequences.

THE RISKS OF HAVING CHILDREN The idea of avoiding disasters has recently been used in an argument for the elimination of undesired genetic traits in our offspring. ${ }^{10}$ It would, according to the argument, be irrational to allow hereditary diseases and disabilities, if these can be avoided by early genetic selection. This is one version of the claim that we should always try to produce the best children we can.

The same logic can, however, be extended to defend the view that all human reproduction is irrational. When people consider the possibility of having children, they confront the following choice. They can decide not to have children, in which case nobody will be harmed or benefited. The value of this choice, in terms of potential future individuals and their lives, is zero. Alternatively, they can decide to have children, in which case a new individual can be born. If this happens, the life of the future individual can be good or bad. The eventual value of the decision, depending on the luck of the reproducers, can be positive, zero, or negative. Since it is rational to avoid the possible negative outcome, when the alternative is zero, it is rational to choose not to have children.

The conclusion relies on the judgment that human lives can sometimes be bad. Individuals who see their own lives as good, and assert that everybody else's life must be similarly assessed have frequently challenged this view. ${ }^{11}{ }^{12}$ Many actual people believe, however, that they would have been better off had they not been born. This is often the essence of the "wrongful life" charges on which individuals have sued their parents or medical providers for damages. ${ }^{13}{ }^{14}$ These legal claims may be controversial, but it cannot be disputed that at least some of the people in question genuinely see their lives as worse than non-existence. 


\section{THE IMMORALITY OF HAVING CHILDREN}

I believe it is morally wrong to cause avoidable suffering to other people. This belief gives rise to two different objections to human reproduction. On the one hand, since all human beings suffer at some point in their lives, every parent who could have declined to procreate is to blame. On the other hand, since potential parents cannot guarantee that the lives of their children will be better than non-existence, they can also be rightfully accused of gambling on other people's lives, whatever the outcome. Because of the uncertainties of human life, anybody's children can end up arguing that it would have been better for them not to have been born at all. The probability of this outcome does not necessarily matter. It is enough that the possibility is real, which it always is.

My moral objections to having children are not necessarily linked with my views on the irrationality of the practice. I do not claim that human reproduction is wrong, because it is irrational. I do believe that it is both morally wrong and irrational, but on slightly separate grounds.

Others have argued that rationality and morality are more closely connected in reproductive matters. According to Julian Savulescu, we have a moral obligation to use new technologies, because it is the only rational choice. ${ }^{11}$ Even he, however, does not insist that the rationality of having children (as he sees it) would always make it immoral not to have them. ${ }^{13}$ apart from this, others have argued that non-existence can, in a rational analysis, always be preferred to life. ${ }^{15}$ This shows, if nothing else, that there are so many arguably defensible accounts of rationality that questions of morality, let alone law and social policy, cannot be settled in a widely accepted manner by appeals to just one of them.

\section{PRACTICAL GUIDELINES}

My reasons for the moral condemnation of having children are, to a certain extent, similar to the reasons I gave for the irrationality of the practice. Both involve the negative outcomes of human reproduction. But their appeals, as I see them, are different, and so are the actions and reactions that they can justify.

In principle, and in an equal discussion between competent participants, my moral views may entitle me to reproach individuals who decide, or have decided, to have children. There is, however, seldom much point in my doing so. If people already have relatively happy progeny, they are not likely to share my views. If their children suffer, I can only increase their unhappiness by telling them that this is exactly why they should not have had them in the first place. And if they are only planning to have children, the prospect of creating suffering will probably not deter them. So, from my own moral point of view, the best strategy is to tolerate their immorality.

With rationality, the situation can be different. When people are making reproductive choices, they are sometimes receptive to ideas concerning the wisest course of action. This is why potential parents often seek counselling, especially in genetic matters. There are problems in delivering advice in a nondirective way; that is, in letting people make their own decisions, which are based on the reasons they see as the best. In a good clinical situation, however, the idea of the irrationality of having children could be a legitimate part of the guidance given. Possible parents could be told that, according to at least one philosopher, it would be all right for them not to reproduce at all. In a social environment where the pressure to procreate makes the choice in the majority of cases less than fully autonomous, this could empower people to make the unpopular, but if my arguments are sound, rational choice, to remain childless. In effect, this would cure their prereproductive stress syndrome.

J Med Ethics 2004;30:377-378.

doi: 10.1136/jme.2003.004424

Correspondence to: $M$ Häyry, Centre for Professional Ethics, University of Central Lancashire, Preston, PRI 2HE;

mhayry@uclan.ac.uk

\section{REFERENCES}

1 Burke W. Genetic testing. N Engl J Med 2002;347:1867-75.

2 Spriggs $M$. Lesbian couple to create a child who is deaf like them. J Med Ethics 2002;28:283.

3 Levy N. Deafness, culture, and choice. J Med Ethics 2002;28:284-5.

4 Anstey KW. Are attempts to have impaired children justifiable? J Med Ethics 2002;28:286-8.

5 Spriggs M, Savulescu J. "Saviour siblings". J Med Ethics 2002;28:289.

6 Spriggs M. Genetically selected baby free of inherited predisposition to early onset Alzheimer's disease. J Med Ethics 2002;28:290.

7 Baumol WJ. Economic theory and operations analysis [2nd ed]. Englewood Cliffs, NJ: PrenticeHall, 1965: ch. 24.

8 Luce LD, Raiffa H. Games and decisions. New York, NY: John Wiley \& Sons, 1957: ch. 13.

9 Rawls J. A theory of justice. Oxford: Oxford University Press, 1972:152-7, 175.

10 Savulescu J. Procreative beneficence: why we should select the best children. Bioethics 2001;15:413-26.

11 Marquis D. Why abortion is immoral. J Philos 1989:86:183-202.

12 Savulescu J. Abortion, embryo destruction, and the future of value argument. J Med Ethics 2000;28:133-5.

13 Feinberg J. Freedom and fulfilment: philosophical essays. Princeton, NJ: Princeton University Press, 1992:14-27.

14 Benatar D. The wrong of wrongful life. Am Philos Q 2000;37:175-83.

15 Benatar $D$. Why it is better never to come into existence. Am Philos Q 1997;34:345-55. 